\title{
The Fertility Transition Revisited: A Cohort Perspective ${ }^{*}$
}

\author{
Tomas Frejka
}

\begin{abstract}
This paper deals with the fertility transition, one of the two essential components of the demographic transition. The analysis demonstrates that by applying the cohort perspective new insights are obtained about how the fertility transition unfolded. Within the overall framework of the fertility transition there were four distinct pathways of fertility trends. Combining these findings with those of other scholars shows that the demographic transition has not yet led to an equilibrium of relatively stable low mortality and stable low fertility.

The four fertility transition pathways are the following: (1) The Western fertility transition pathway characterized by major cohort total fertility rate (CTFR) fluctuations; (2) the South European fertility transition pathway characterized by an almost uninterrupted CTFR decline; (3) the Central and East European fertility transition pathway characterized by stable CTFRs in the 1920s to 1950 s cohorts and a decline in the 1960s and 1970s cohorts; (4) the East and South-East Asia fertility transition pathway characterized by a late start in the mid-20 $20^{\text {th }}$ century with rapidly declining CTFRs.

The exploration of societal conditions shaping fertility trends in the $19^{\text {th }}$ and $20^{\text {th }}$ centuries confirms Notestein's conclusions that the causes are a complex combination of "technological, social, economic, and political developments" as well as cultural and ideational effects, and that it is "impossible to be precise about the various causal factors". At times the primary factors were economic, as in the Great Depression of the 1930s and the 1960s post-war prosperity in Western countries. However, these economic factors also had many political, cultural, social, policy and other important facets. In Central and Eastern Europe the primary factors during the era of state socialism were the political system and social policies. The patriarchal nature of societies was the prime factor shaping fertility trends in Southern Europe and in East and South-East Asia.
\end{abstract}

Keywords: Fertility transition pathways · International comparative analysis $\cdot$ Cohort fertility $\cdot$ Fertility transition causes

This article contains supplementary material in the form of an online Appendix: DOI 10.12765/ CPoS-2017-10en,

URL: http://www.comparativepopulationstudies.de/index.php/CPoS/article/view/272/244. 


\section{Introduction}

This paper deals primarily with the fertility transition, one of the two essential components of the demographic transition. The analysis in this paper demonstrates that by applying the cohort perspective new insights can be obtained about how the fertility transition unfolded. Such an analysis can be performed because a sufficient amount of cohort fertility data series have been assembled for many of the same populations for which period data were available about a century ago, when the initial portrayals of the demographic transition were introduced. Also, enhanced insights are now possible due to significant progress in the science of demography and in statistical analysis, which has enabled the application of cohort fertility measures elaborated by Ryder (1951 and 1964). The new findings show that - within the overall framework of the fertility transition - there were at least four distinct pathways of fertility trends in the countries examined here. Moreover, combining my findings with those of other scholars shows that thus far the demographic transition has not led to an equilibrium of relatively stable low mortality and stable low fertility.

Over 70 years have passed since the demographic transition theory was elaborated at the Office of Population Research (OPR) of Princeton University. In the words of Dudley Kirk, "by convention, Frank Notestein's article published in 1945 (Notestein 1945) is regarded as its first definition" (Kirk 1996: 361). This was complemented by another, lesser known but arguably equally important paper (Notestein 1953), which examined the causes of the demographic transition in greater detail and spelled out the implications for research, policy development, and actions. This was at a time when the demographic transition had been taking place only in Europe and the overseas countries with populations of European origin, at a time when 70 percent of the world's 2.5 billion inhabitants was in the pre-transitional stage of high mortality and high fertility. Yet Notestein foresaw the demographic transition would spread to the remainder of the World, including the need for "speeding the processes of social change in directions that yield falling birth-rates, which in turn will permit more rapid increases in per capita income" (Notestein 1953: 25).

The empirical basis for Notestein's development of the theory of the demographic transition consisted of data compiled by the British demographer Alexander CarrSaunders in World Population: Past Growth and Present Trends (1936), "a massive ... compendium of materials relating to population size and demographic change in many countries" (Kirk 1996: 363), together with research conducted at the Princeton OPR in the early 1940s and published in several volumes dealing with European 
populations and their prospective growth (Notestein et al. 1944; Moore 1945; Kirk 1946; Lorimer 1946). ${ }^{1}$

The essence of the fertility transition consists of a transformation from extensive reproduction where many children are born yet few survive, to the reverse, and a transformation from generally unplanned to planned parenthood. Notestein (1953: 17) described the circumstances that generated the demographic and fertility transitions as follows:

The new ideal of the small family arose typically in the urban industrial society. It is impossible to be precise about the various causal factors, but apparently many were important. Urban life stripped the family of many functions in production, consumption, recreation, and education. In factory employment the individual stood on his own accomplishments. The new mobility of young people and the anonymity of city life reduced the pressures toward traditional behaviour exerted by the family and community. In a period of rapidly developing technology new skills were needed, and new opportunities for individual advancement arose. Education and a rational point of view became increasingly important. As a consequence the cost of child-rearing grew and the possibilities for economic contributions by children declined. Falling death-rates at once increased the size of the family to be supported and lowered the inducements to have many births. Women, moreover, found new independence from household obligations and new economic roles less compatible with child-rearing.

The principal circumstances and motivations for people to want, have and be able to have small families are valid to this day, even though we are living in a postindustrial society. Increasing shares of people are living in urban areas, technologies are undergoing continuous improvements, productivity is increasing, the need for education is never-ending, availability and use of contraceptive means as well as legal induced abortions have been increasing, and gender relations continue to change.

It is the changing of gender relations - the gender revolution - which has increasingly become the focus of attention. Several scholars have engaged in theoretical and empirical analyses to investigate the fertility effects of the gender revolution. Findings in three recent papers are representative (Esping-Andersen/Billari 2015; Goldscheider et al. 2015; Anderson/Kohler 2015). All three consider a reversal of fertility trends (i.e. an increase) to be in the offing as a result of the progress in the gender revolution. However, as will be discussed below (section 4.2.3), the analysis of available cohort data in the \pm 35 populations analyzed does not yet indicate a reversal of fertility trends presumed to occur as a consequence of the gender revolution.

1 Three scholars had described and discussed the principal contours of modern mortality and fertility trends before Notestein. Adolphe Landry (1909) published the first crude formulation of the demographic transition in an article which he later developed extensively in his book $L a$ révolution démographique (1934). Warren Thompson (1929) elaborated an early version of the demographic transition in an article entitled "Population". Finally, the British demographer Alexander Carr-Saunders published the volume World Population: Past Growth and Present Trends in 1936. 
Also, there is no doubt that many demographic characteristics pertaining to unions, fertility, and societal backgrounds have been changing over time and were significantly different in the last third of the $20^{\text {th }}$ and in the early $21^{\text {st }}$ centuries compared to the $19^{\text {th }}$ century and to the first two-thirds of the $20^{\text {th }}$ century. These realities have been eloquently discussed and advanced as the Second Demographic Transition (SDT) in papers by Lesthaeghe, van de Kaa and others (Lesthaeghe/van de Kaa 1986; Lesthaeghe 2010). Many specific characteristics pertaining to marital and informal unions, fertility, and societal backgrounds have changed, as outlined by the SDT theory. Regarding the basic demographic developments of the past two centuries, in my view the SDT and the Demographic Transition as described by Notestein do not appear to be two contrasting systems; rather the SDT is a natural, more detailed component of Notesteins's assessment. Mortality continues to decline and the basic fertility trends depicted in the cohort fertility measures have been fluctuating as shaped by, in Notestein's words (1945: 36), the "technological, social, economic, and political developments" of the past 70 years.

At the same time, significant progress has been made in vital data registration and data collection, in the development of the science of demography and in statistical analysis, which has enabled the application of cohort fertility measures elaborated by Ryder (1951 and 1964). Thus we can describe and examine fertility trends not only over the 70 years since Notestein's formulation of the demographic transition, but it is also possible to arrive at an improved, more profound understanding of the fertility trends during the past two centuries, i.e. during the entire course of the demographic transition. Long-term cohort total fertility rate series have been assembled for 36 populations and these will be scrutinized and analyzed in the remainder of this paper. It turns out that this analysis of the fertility transition reveals characteristics that cannot be observed when using period measures.

Having reviewed the rationale and background for the research reported on in this paper in section 1 (above), section 2 presents data used and methods applied. Section 3 provides an overview of the dynamics of four pathways of the fertility transition as revealed by using cohort rather than period measures. In section 4, basic societal conditions shaping fertility trends of the past two centuries are discussed. The findings of this research are summarized in section 5 .

\section{Data and methods}

The principal methodological innovation of this investigation is to use the cohort total fertility rate (CTFR) as the measure for analyzing the fertility transition. In contrast to the period total fertility rate (PTFR), the CTFR reflects only the quantum of fertility whereas in the PTFR the quantum of childbearing is modified by the timing of childbearing within each cohort. This is especially important when comparing trends between PTFRs and CTFRs. PTFRs tend to be variable and volatile from year to year. Even more importantly, during periods when childbearing is being advanced, PTFRs are inflated and, vice versa, when childbearing is being postponed, PTFRs are deflated (Ryder 1951; Bongaarts/Feeney 1998; Frejka 2011). It turns out that these dy- 
namics can be crucial for the present analysis because in general the effects of basic societal, i.e. economic, social, cultural, and political developments in the respective societies may be better reflected in CTFR rather than in PTFR levels and trends. The data assembled and analyzed in this paper come from the following documents and collections of data:

Festy (1979), archives of the Observatoire Démographique Européen (2012), Sardon (1991), the Human Fertility Database (2016), Heuser (1976), Hamilton/Cosgrove (2010, 2012), Myrskylä et al. (2013), Sobotka (2016), Spéder (2016), Frejka et al. (2010) and personal communications from Puur (2016), Stankuniene (2016), Tymicki (2016), Zeman (2016), and Zakharov (2008, 2016).

Only cohort total fertility rates (CTFRs) are dealt with in this paper, although the fertility transition also involves changes in cohort parity distributions, cohort parity progression ratios, and changing age patterns of cohort childbearing. The latter are not dealt with in this paper.

Two methods were applied in the listed sources to derive cohort total fertility rates data:

- Age-specific cohort fertility rates are computed using original birth registration statistics compiled by single year of age and single year birth cohort of mother. The age-specific cohort fertility rates are subsequently applied to compute cohort total fertility rates, cohort fertility rates by birth order, cohort fertility progression rates and cohort parity distributions.

- Cohort total fertility rates are derived from children ever born (CEB) in population censuses. The average numbers of CEB are computed for single-year birth cohorts of women usually aged 40 (or 45) to 80 (or 85 ) years at the time of the census. Several censuses are used and averages for the respective birth cohorts from available censuses are applied. This method is less reliable than the one based on registration data if for no other reason than that only data for women surviving to the census date enter the computations. Even though inaccurate, these data are sufficiently reliable to delineate trends.

While it is preferable to use single year data, averages for several cohorts, most often for five-year clusters of cohorts, were also used. This tends to be dictated by data availability. As a rule, single-year data were used primarily in $20^{\text {th }}$ century analyses, broader year groupings for earlier ones. This is reflected in the presentation of the data in Figure 2 (broader groupings) and in Figures 3 to 7 (single year birth cohorts). It would also have been preferable to have and analyze continuous time series of cohort total fertility rates (CTFRs) for individual countries from the early $19^{\text {th }}$ century to the end of the $20^{\text {th }}$. Such series are at present available for only a few populations. Thus for the analysis the several-cohort averages in Figure 2 have to be combined with the single year-cohort data from other sources in subsequent Figures 3-6.

Geographic groupings are not strictly uniform for different time periods. They follow accepted and familiar conventions. For $19^{\text {th }}$ and early $20^{\text {th }}$ century analysis the classification used by Festy (1979) is followed as specified in Figure 2. For the remainder the classifications are similar to what is customary in contemporary professional literature (for instance, Lutz et al. 2014). Specifically, the following classifi- 
cation of the 36 populations for which it was possible to assemble long-term series of cohort fertility measures into regions and sub-regions is used:

The Western region consists of the following sub-regions:

- Northern Europe: Denmark, Finland, Norway, and Sweden;

- Western Europe: Belgium, England and Wales, France, and Netherlands;

- Overseas English-speaking countries: Australia, Canada, New Zealand, and United States;

- German-speaking countries: Austria, Switzerland, and West Germany.

Southern Europe:

- Greece, Italy, Portugal, and Spain.

The Central and East European (CEE) region consists of the following sub-regions:

- Central Europe: Czech Republic, ${ }^{2}$ Hungary, Poland, and Slovakia;

- South-Eastern Europe: Bulgaria, Romania, and Serbia;

- Eastern Europe: Belarus, Russia, and Ukraine;

- Baltic countries: Estonia and Lithuania.

East and South-East Asia:

- Hong-Kong, Japan, Singapore, South Korea, and Taiwan.

An Appendix is attached which provides all cohort total fertility rate series depicted in the figures organized by countries and regions as listed above.

\section{The fertility transition}

Together with the scientific, industrial and technological revolutions, and with the fundamental transformation of the systems of governance, including the proliferation of democratic regimes, the two pillars of the demographic transition - the mortality and fertility transitions - rank among the fundamental societal transformations of recent centuries. By the early $21^{\text {st }}$ century, the fertility transition from high to low fertility, from large to small families, had been occurring in most populations around the globe. As will be described and discussed in sections 3 and 4 below, pathways of the fertility transition may acquire distinct characteristics in diverging societal conditions. So far, this does not appear to be the case with the mortality transition. Recent research regarding mortality trends (Oeppen/Vaupel 2002; Shkolnikov et al. 2011) has however upended long-lasting accepted perceptions. Until recently it was assumed that mortality decline would reach a limit and not decrease any further. New research results have shown that mortality was continuously declining and life expectancy increasing throughout the $20^{\text {th }}$ and early $21^{\text {st }}$ centuries and will continue

$\overline{2}$ As will be shown below the Czech Republic is a special case. Its cohort total fertility trends are typical for the Western region approximately up to the 1920 birth cohort and fit the Central and East European pathway from thereon. Thus the Czech Republic is included not only in Panel C, but also in Panel A in Figure 6. 
to do so for several decades. This means that the mortality transition has not been concluded yet.

As much as I would want to conduct a worldwide analysis using cohort fertility data, there are many populations in Asia, Latin America and Africa for which this cannot be done yet due to the unavailability of long-term data series. For the time being, an examination of the available data shows that such an analysis can be conducted for about 35 populations. Within the overall framework of the decline from high to low fertility, four different pathways have materialized: one in Western populations, a different one in South European countries, a third one in Central and Eastern Europe, and a fourth one in East and South-East Asia.

Data from a number of different sources have to be combined to elucidate pathways of the fertility transition. For the most part, long-term cohort fertility data series comprising not only $20^{\text {th }}$ century cohorts but also those of the $19^{\text {th }}$ century can be assembled for a considerable number of the populations in Northern and Western Europe, the German-speaking countries, as well as the overseas populations of European origin. These represent the group of Western populations in this investigation. For most other countries data are available mainly for $20^{\text {th }}$ century birth cohorts. Exceptionally, data are also available for the $19^{\text {th }}$ century, including two out of the four principal South European populations. In the third and fourth groups - the Central and East European and the East and South-East Asian ones such cohort fertility series are available only for very few populations.

\subsection{The Western World}

Cohort total fertility rates (CTFRs) were generally quite steady with between four and five births per woman born in the 1830s-1840s in the Western group of populations (Fig. 1). ${ }^{3}$ Compared to typical traditional societies where women usually had six to seven life-time births, fertility was relatively low. This was in large part due to the "distinctive marks" of the European marriage pattern with a high age at marriage and where a large proportion of people never married at all (Hajnal 1965: 101).

Fertility started to decline towards the end of the $19^{\text {th }}$ century among women born in the 1840s, 1850s and 1860s in a majority of these countries (Fig. 1). The meaningful childbearing descent occurred between about 1880 and 1930. In Norway, for instance, the CTFR declined from 4.4 births per woman in the 1855-1859 cohorts to 2.0 births per woman in the 1905-1910 birth cohorts. Similar cohort fertility declines occurred in most North, West, Central and South European countries during this 50 year period. The CTFR declined from between 4-5 births per woman

3 As elaborated in section 2 Data and methods, data obtained from Festy (1979) for the 19th and early $20^{\text {th }}$ century cohorts in Figure 1 are presented in \pm 5 year birth cohort groups, whereas data in the subsequent Figures are single-year birth cohorts 
Fig. 1: Cohort total fertility rates, selected countries, Northern, Western, German-speaking countries and Southern Europe, Overseas Englishspeaking countries, birth cohorts $1835-1920$

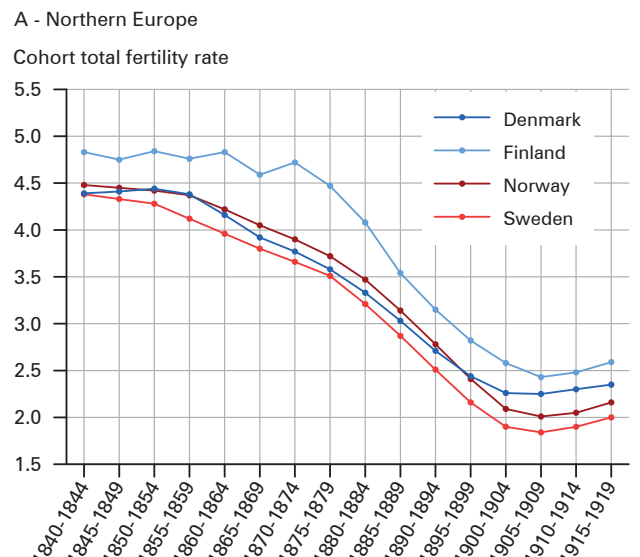

Birth cohort

C - German-speaking countries and Southern Europe Cohort total fertility rate

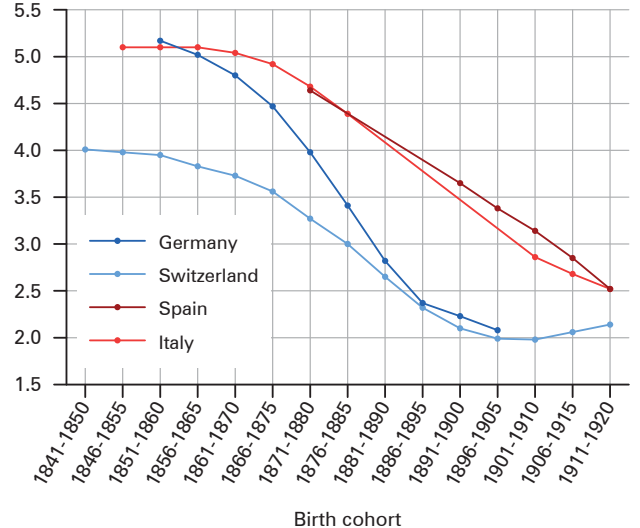

Source: Festy 1979: 58-65

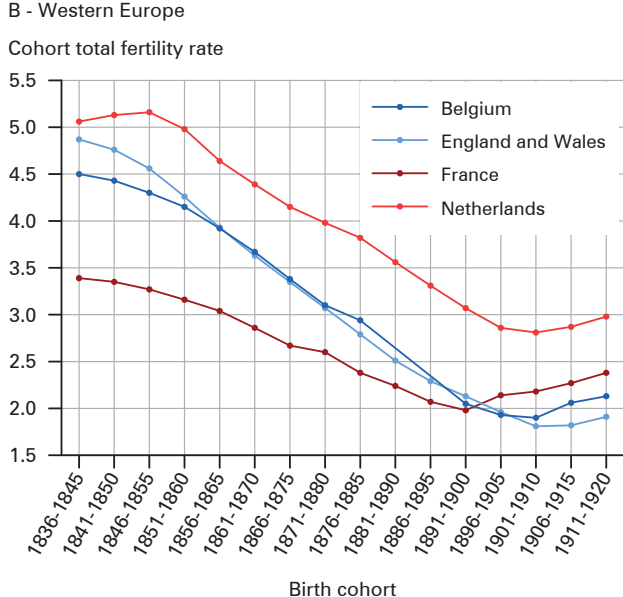

D - Overseas English-speaking countries Cohort total fertility rate

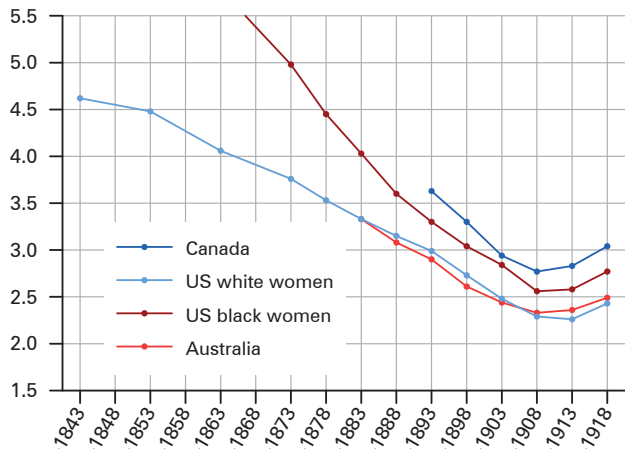

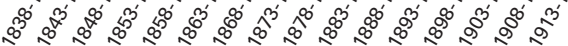

Birth cohort

in the generations born in the middle of the $19^{\text {th }}$ century to $1.8-2.4$ births per woman born early in the $20^{\text {th }}$ century. ${ }^{4}$

4 There were two exceptions where fertility began to fall earlier, France and the United States. Notestein (1945: 40) provided the following explanations: "In France the secularizing influence of the French Revolution was undoubtedly important. In the United States the birth rate has been dropping since the beginning of the nineteenth century, but the rates have moved down from exceptionally high levels which characterized a frontier society that was unusually favorable to high fertility." 
Fig. 2: Cohort total fertility rates, selected countries, Northern and Western Europe, German-speaking countries, Overseas English-speaking countries, birth cohorts 1870-1978

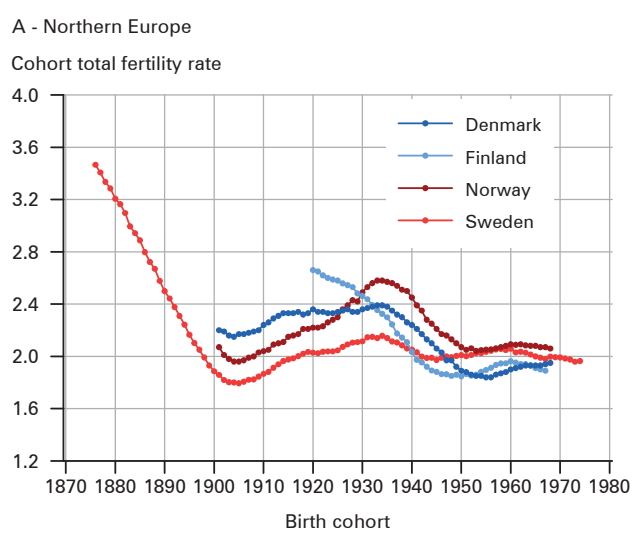

C - German-speaking countries

Cohort total fertility rate

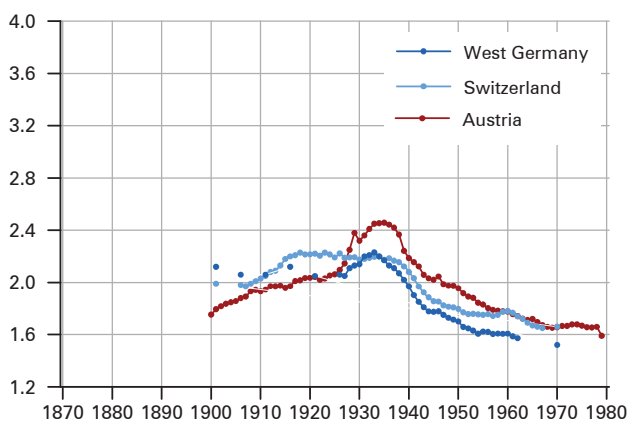

Birth cohort

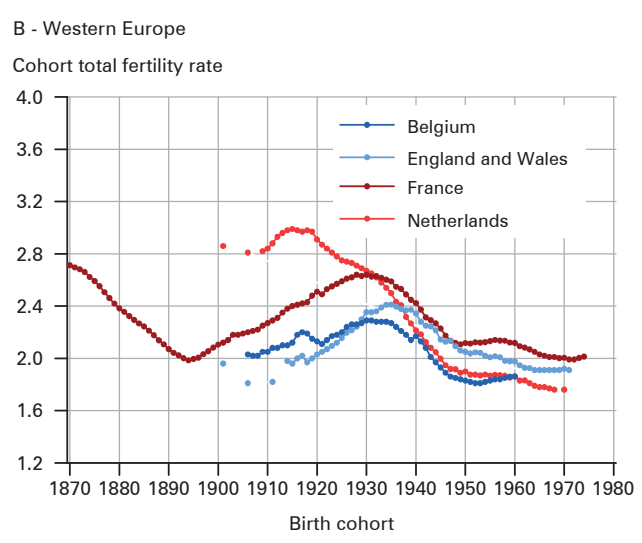

D - Overseas English-speaking countries

Cohort total fertility rate

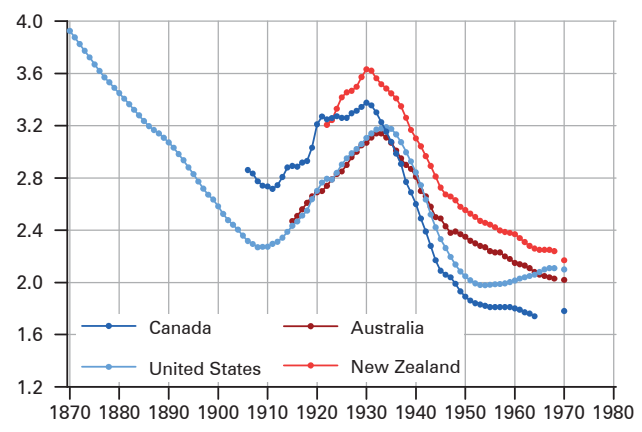

Birth cohort

Source: Hamilton/Cosgrove 2010 and 2012; Heuser 1976; Human Fertility Database; Myrskylä et al. 2013; ODE 2012; Sardon 1991; Sobotka 2016

The CTFRs of women born early in the $20^{\text {th }}$ century did not remain this low, i.e. around two births per woman, but started to increase to reach high points among women born in the early 1930s (Fig. 2, Panels A-D). They created the baby-boom of the late 1950s/early 1960s throughout the Western World. The zeniths ranged from CTFRs of 2.2 births per woman in Sweden to 3.6 in New Zealand.

There was a great deal of variation in the CTFR trends for most of the $20^{\text {th }}$ century in this group of populations. It is however remarkable that these trends unfolded along similar paths. The CTFRs increased considerably starting with women born around 1910 through those born around 1930 in Northern and Western Europe, in the German-speaking countries and in the overseas populations of European origin (Fig. 2, Panels A-D). This was followed by an equally notable CTFR decline which levelled off among the 1950s and 1960s birth cohorts at between 1.8 and 2.2 births per woman in Northern and Western Europe and in the United States. The decline con- 
tinued in the 1950s and 1960s generations in Australia, New Zealand and Canada. In the German-speaking countries the CTFRs also continued to fall among the 1950s and 1960s cohorts, reaching levels around 1.6 births per woman (Fig. 2, Panel C).

\subsection{South European populations}

South European populations experienced a slower cohort fertility decline compared to the other countries among women born in the $19^{\text {th }}$ century (Fig. 1, Panel C). The CTFR of women born around 1860 in Italy and Spain dropped from around 5.0 to around 3.0-3.5 births per woman for those born around 1900, compared to a falloff to around 2.0 births per woman in Northern and Western Europe and in the German-speaking countries (Fig. 1, panels A-C). The CTFRs then continued to decline among South European women of the 1900s and 1910s birth cohorts to a plateau among the 1920s and 1930s birth cohorts (Fig. 3). The decline resumed in the 1940s cohorts to attain a low at around 1.6 births per woman among the cohorts of the mid 1960s (Fig. 3). Apparently CTFRs continued to descend even further among the 1970s birth cohorts. In Spain the women born in the mid-1970s had an estimated CTFR of around 1.4 births per woman.

Fig. 3: Cohort total fertility rates, selected countries, South European populations, birth cohorts $1901-1974$

Cohort total fertility rate

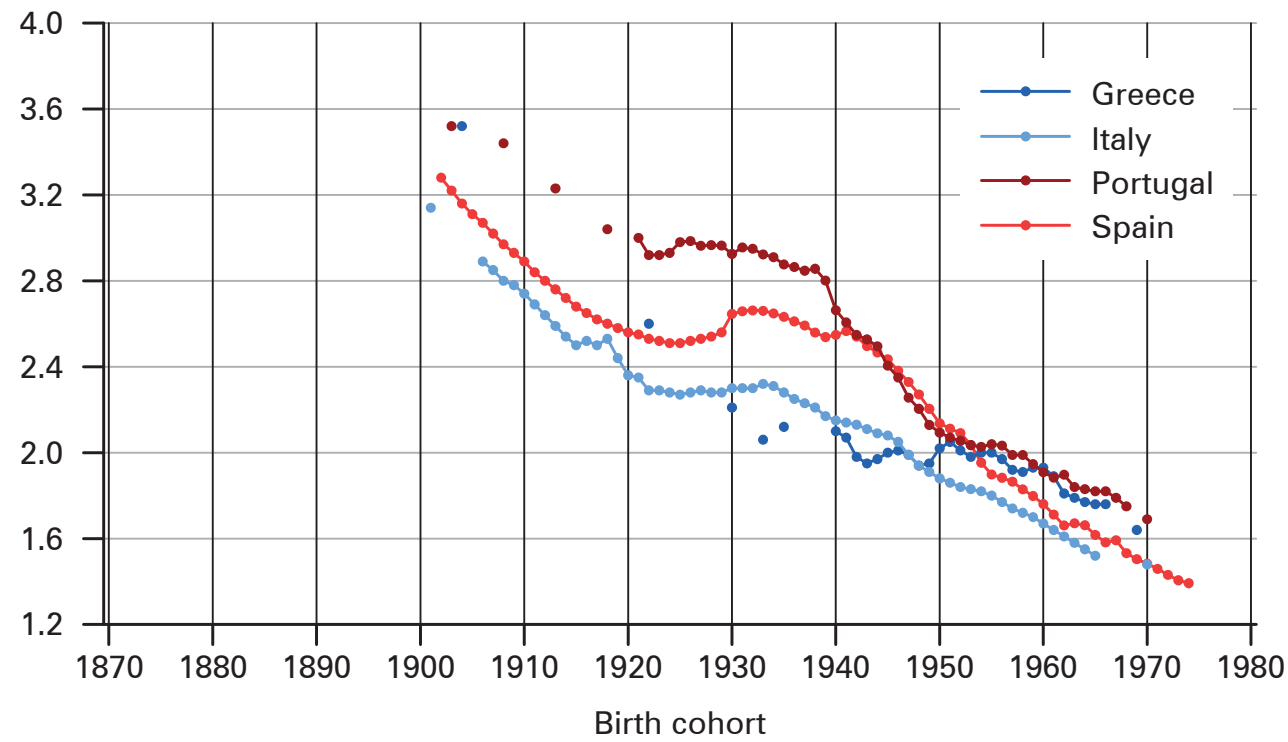

Source: Human Fertility Database 2016; Myrskylä et al. 2013; ODE 2012; Sardon 1991; Sobotka 2016 


\subsection{Central and Eastern Europe}

Cohort fertility data are available for quite a number of Central and East European populations, but at times for relatively short series. For the $19^{\text {th }}$ and early $20^{\text {th }}$ centuries data are available for Russian, Czech and Slovak women (Fig. 4). Zakharov (2008: 910 and 955, and personal communication 2016) assembled cohort total fertility rates for Russia starting with the 1841 birth cohort with projections for cohorts born in the late 1960s and the 1970s (Fig. 4, Panels $C$ and D). ${ }^{5}$ For a considerable part of the $19^{\text {th }}$ century, i.e. for the women born between 1840 and 1880, CTFRs were around seven births per woman (Fig. 4, Panel C). In Russia fertility started to decline among women born around 1880, however the CTFR was still above four births per woman among those born early in the $20^{\text {th }}$ century (Fig. 4, Panels $C$ and D), considerably higher than in West European populations.

The trends in cohort total fertility rates vaguely resembled those of Western countries, particularly among Slovak and certainly among Czech women (Fig. 4, Panel A). For instance, the CTFR trends of Czech and Swedish women of the 1870s through 1910s birth cohorts were close to each other. The Swedish 1880 CTFR was 3.2, the Czech 1880 CTFR was 3.1 births per woman; both declined to approximately 1.8 for the 1902 CTFR and thereafter increased moderately; Sweden's 1915 CTFR was 2.0, the Czech 1915 CTFR was 2.2 births per woman. ${ }^{6}$

Starting with women born in the late 1920s and the 1930s through those born in the 1950 s, i.e. those bearing children predominantly during the state-socialist period, CTFR trends in Central and Eastern Europe differed substantially from Western countries (Fig. 4). CTFR trends were relatively stable, proceeding in a quite narrow band at around two births per woman (Sobotka 2004, 2011; Frejka/Gietel-Basten 2016).

Cohort total fertility rates throughout CEE started to decline with women born around 1960 (Fig. 4). This was apparently engendered by the collapse of the state socialist systems and the onset of the transition to contemporary capitalism (Sobotka 2004, 2011; Frejka/Gietel-Basten 2016). Thus far, CTFRs of the late 1960s and the 1970s birth cohorts center around 1.6 births per woman (Fig. 5).

5 In Figure 4, Panel D, the vertical and horizontal scales are identical to all other graphs, but different scales are used in Panel C to show the levels of the CTFRs in Russia for cohorts born in the $19^{\text {th }}$ and early $20^{\text {th }}$ centuries.

Differences between crude birth rates (CBRs) for Czech and Russian women provide additional support for the notion that Czech fertility during the $19^{\text {th }}$ century resembled West European patterns. The Czech CBR declined from 43 births per thousand inhabitants around 1800 to 35 around 1900. Russia's CBR was around 50 births per thousand inhabitants throughout the second half of the 19th century (Pavlík 1964: 94 and 134). 
Fig. 4: Cohort total fertility rates, selected countries, Central, South Eastern, Eastern Europe, Baltic countries, birth cohorts 1840-1980

A - Central Europe 1870-1979

Cohort total fertility rate

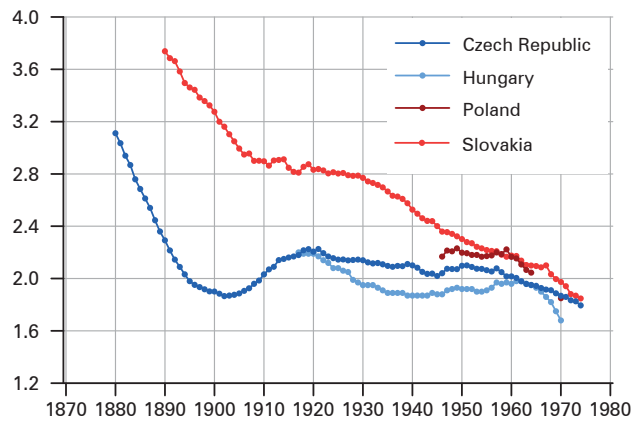

Birth cohort

C - Russia 1840-1920

Cohort total fertility rate

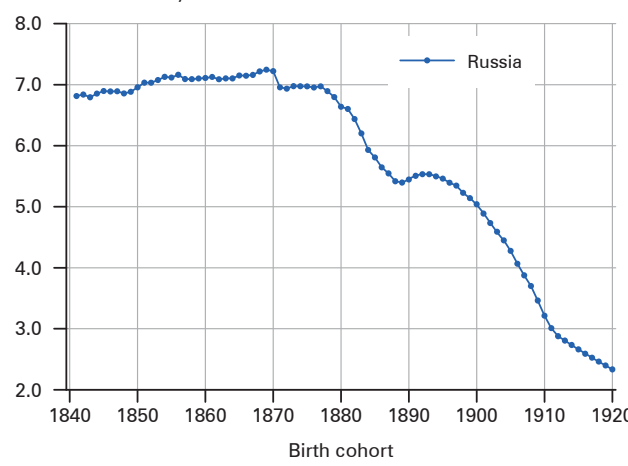

E - Baltic countries 1870-1980

Cohort total fertility rate

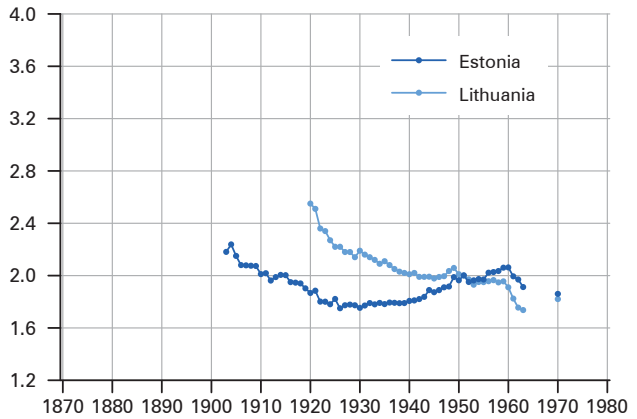

Birth cohort
B - South-Eastern Europe 1870-1979

Cohort total fertility rate

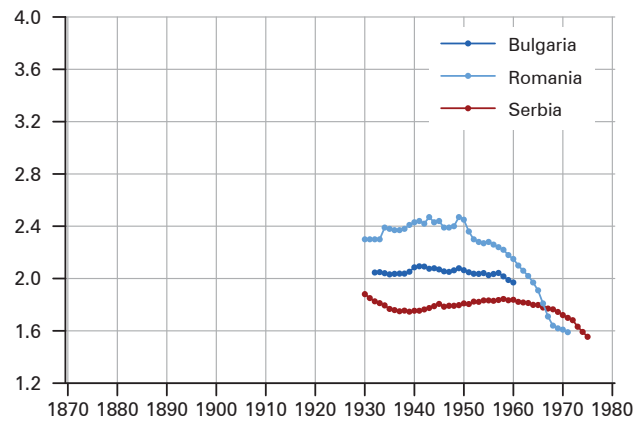

Bith cohort

D - Eastern Europe 1870-1980

Cohort total fertility rate

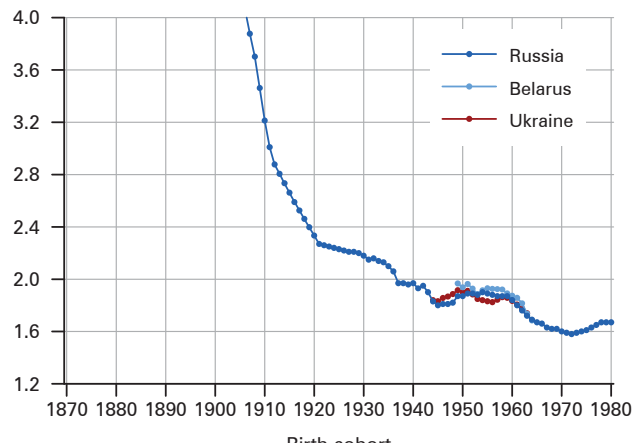

Note: The available CTFR series for Russia starts in 1840, therefore panel C has different horizontal (ranging from 1840-1920, rather than 1870-1980) and vertical axis scales (ranging from 2.0-8.0, rather than 1.2-4.0).

Source: Human Fertility Database 2016; Myrskylä et al. 2013; Puur 2016; Sobotka 2016; Stankuniene 2016; Spéder 2016; Tymicki 2016; Zakharov 2016 


\subsection{East and South-East Asia}

CTFR data for women born in the $19^{\text {th }}$ and early $20^{\text {th }}$ century are available only for South Korea. These indicate that rates among these women were around 5.0 births per woman (Fig. 5). A clear decline started among women of the 1920s birth cohorts in the middle of the $20^{\text {th }}$ century. This steep CTFR descent in South Korea continued for several decades.

The relatively sparse cohort fertility data available for Singapore, Taiwan and Hong Kong indicate a similarly precipitous fertility decline for the birth cohorts of the 1940s, 1950s and 1960s (Frejka et al. 2010; Fig. 5).

Japan constitutes an exception; there the cohort fertility transition must have been under way several decades earlier. The CTFR of the 1930 birth cohort was already close to 2.0 births per woman and remained at that level through the birth cohorts of the mid-1950s. This was followed by a cohort fertility decline among the women born in the late 1950s and 1960s which was very similar to that of the other East and South-East Asian countries.

Women completing their childbearing early in the $21^{\text {st }}$ century in this region are winding up with CTFRs below 1.6 births per woman, in particular in Hong Kong where the late 1960s CTFRs were around 1.2 births per woman (Fig. 5; Fig. 6, panel D).

Fig. 5: Cohort total fertility rates, selected countries, East and South-East Asia, birth cohorts 1888-1972

Cohort total fertility rate

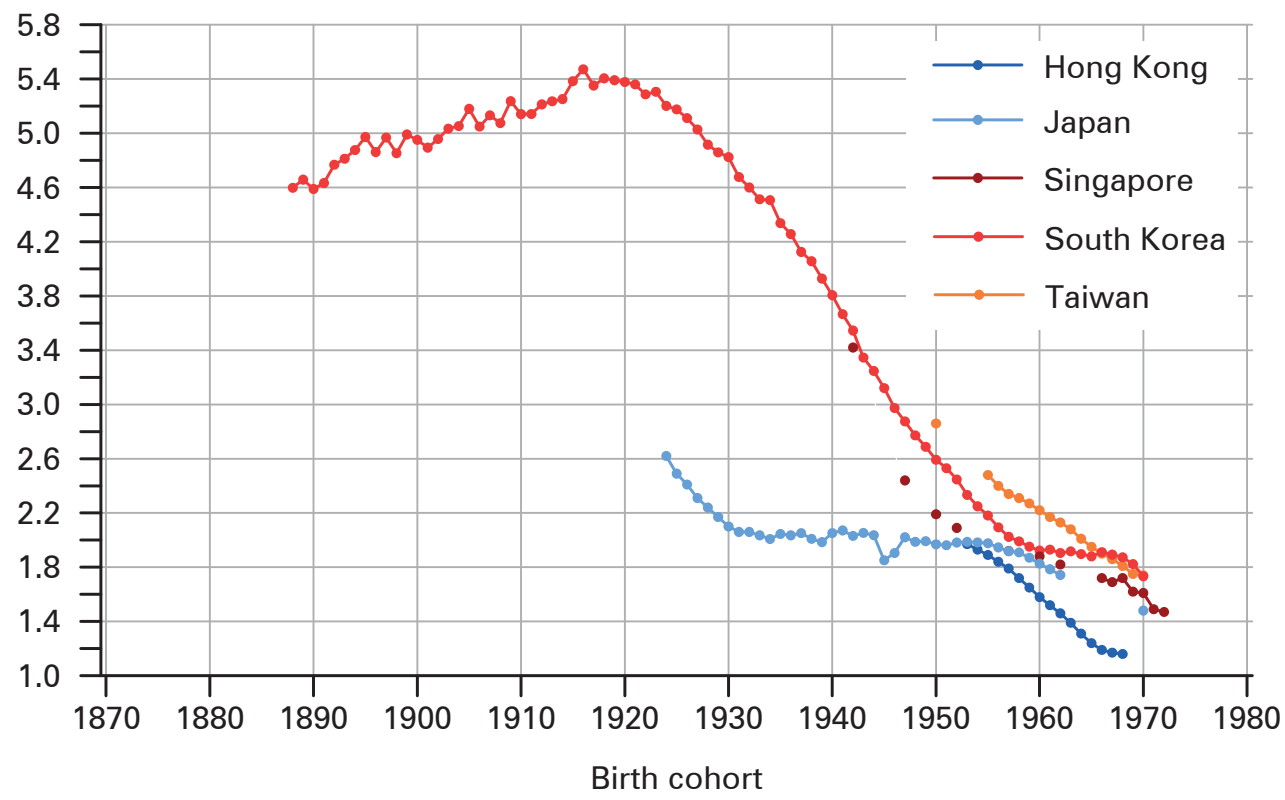

Source: Frejka et al 2010; Myrskylä et al. 2013; Zeman 2016 
Fig. 6: Cohort total fertility rates, selected countries, Western populations, South European populations, Central and East European populations, East and South-East Asia populations, birth cohorts 1870-1980

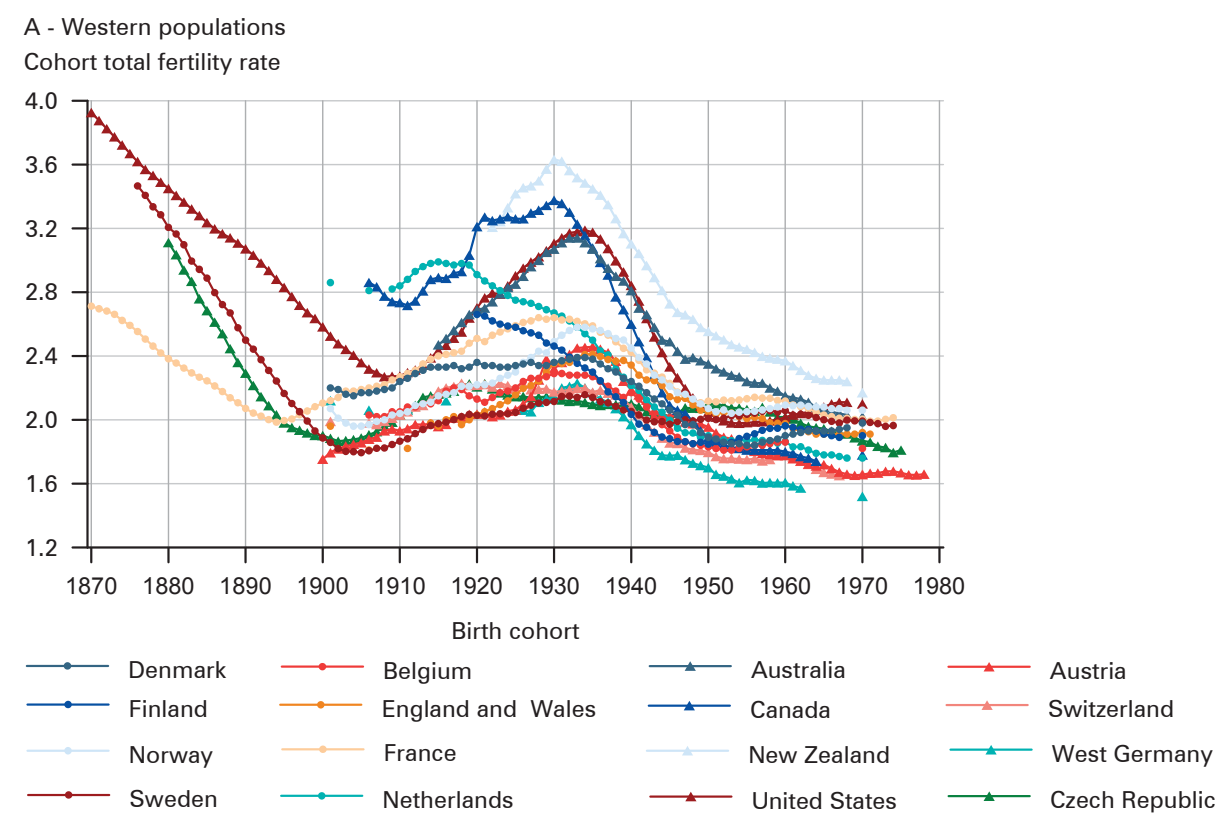

B - South European populations

Cohort total fertility rate

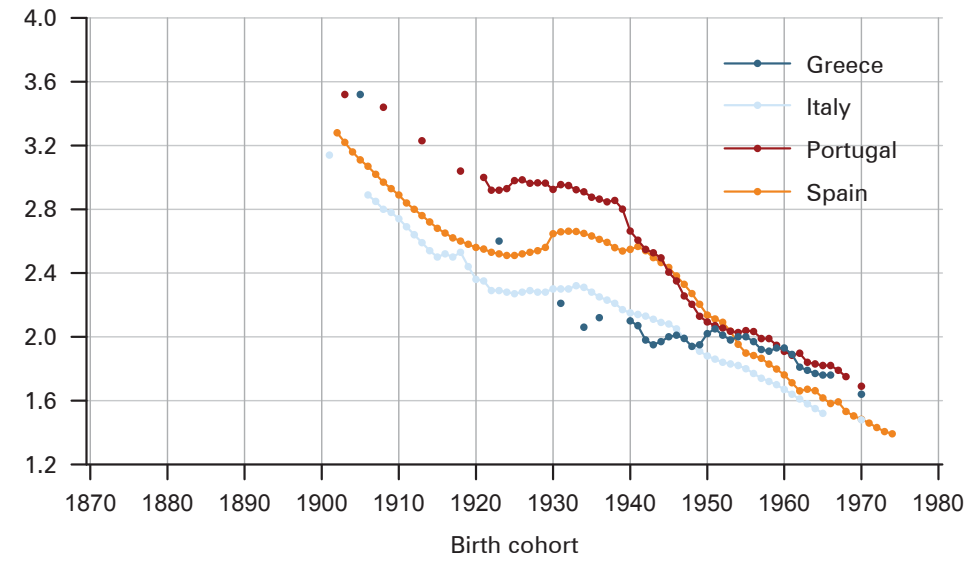


Fig. 6: Continuation

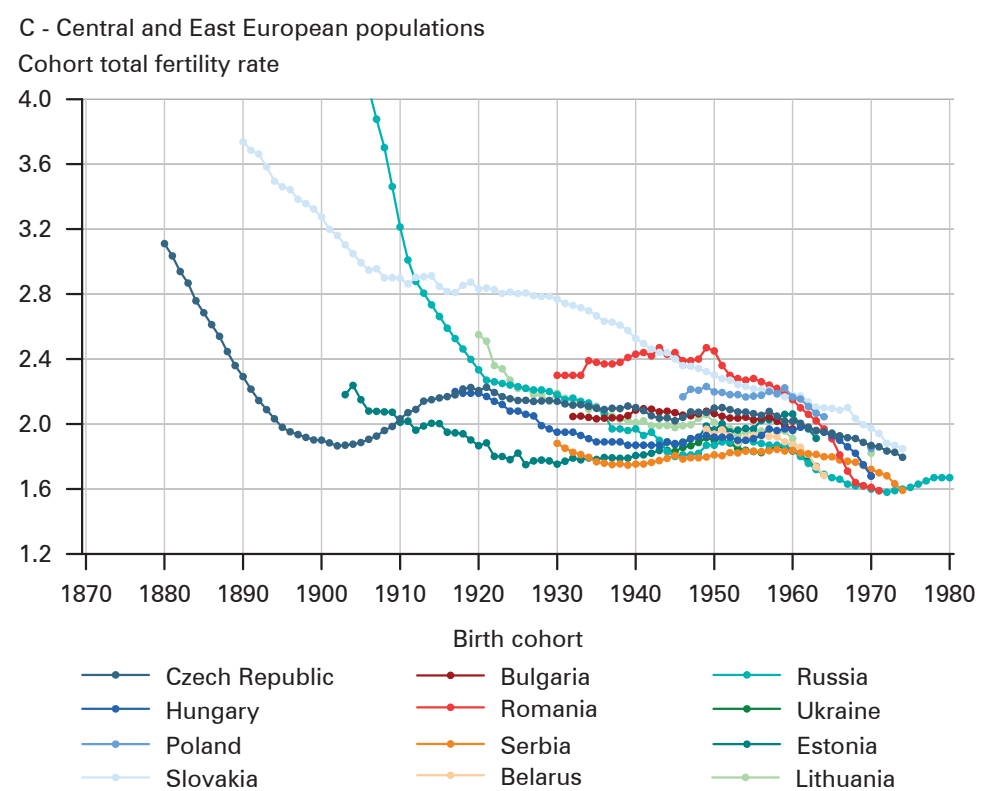

D- East and South-East Asia populations Cohort total fertility rate

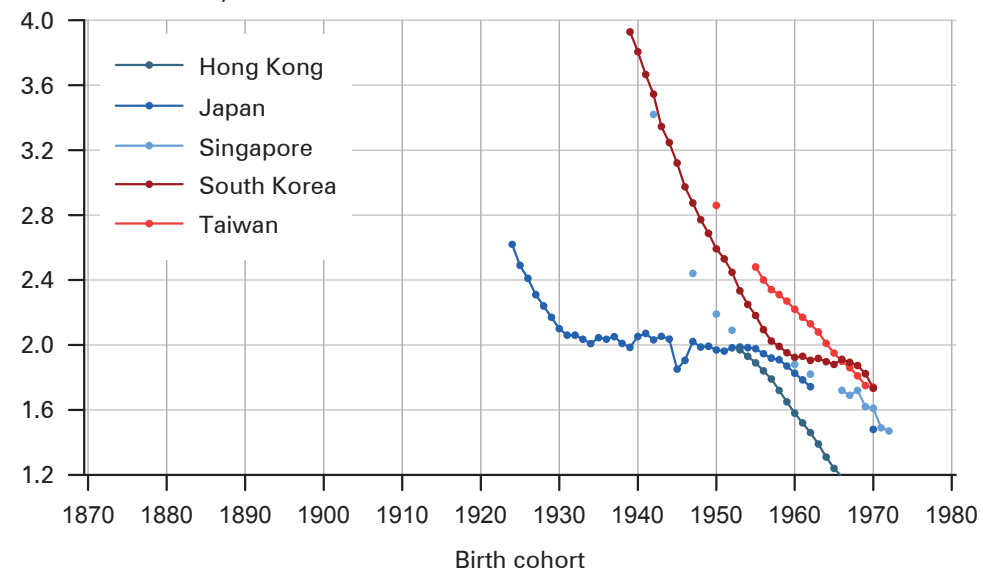

Source: Hamilton/Cosgrove 2010 and 2012; Heuser 1976; Human Fertility Database; Myrskylä et al. 2013; ODE 2012; Sardon 1991; Sobotka 2016

In sum, within the overall framework of the decline from high to low fertility, using available completed cohort fertility rates I have identified four fertility transition pathways from the $19^{\text {th }}$ through the early $21^{\text {st }}$ century: The Western fertility transi- 
Fig. 7: Stylized pathways of fertility transitions, cohort total fertility rates, Western populations, Central and East European populations, South European populations, East and South-East Asia populations, birth cohorts 1870-1970

Cohort total fertility rate

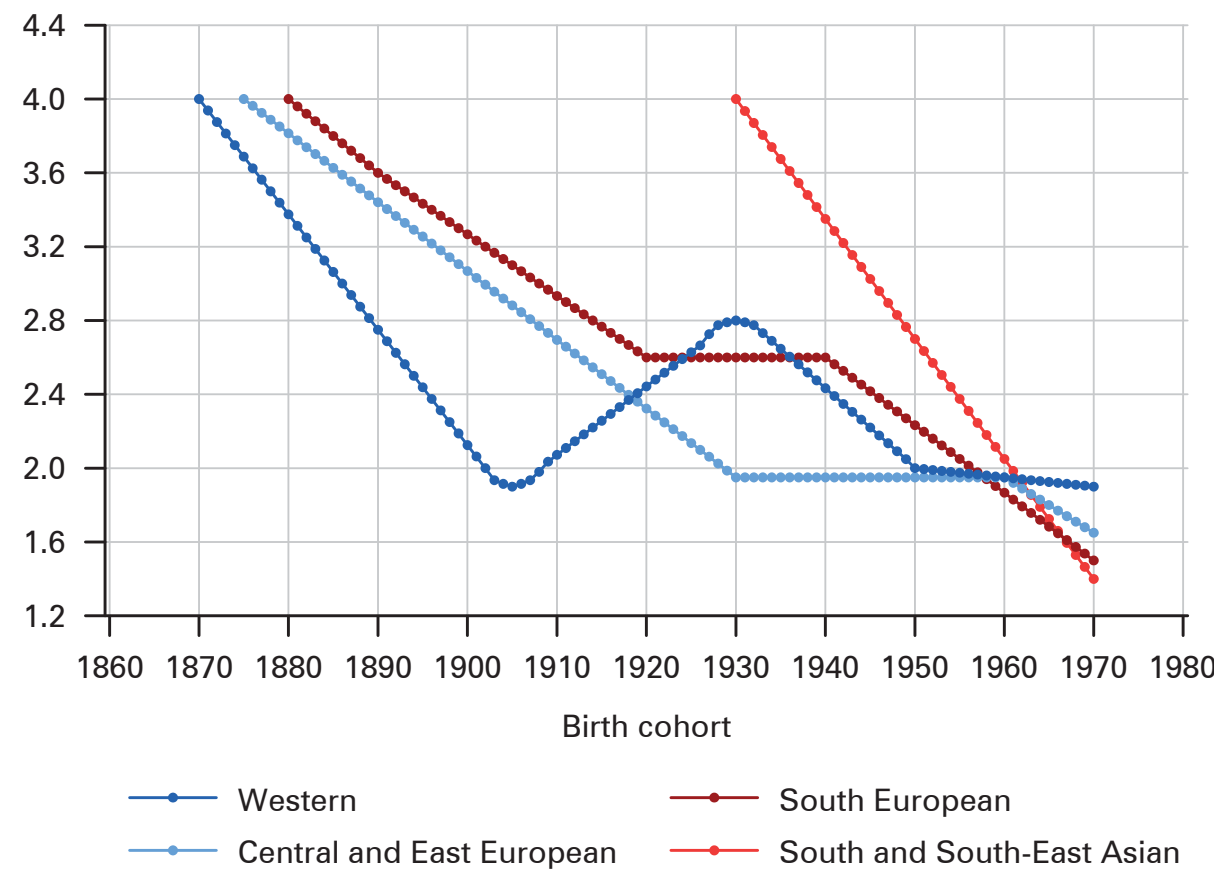

Source: Author's design

tion pathway, the South European fertility transition pathway, the Central and East European fertility transition pathway, and the East and South-East Asian fertility transition pathway (Fig. 6). Figure 7 illustrates these four fertility transition pathways in a stylized form.

\section{Societal conditions shaping fertility trends of the $19^{\text {th }}$ and $20^{\text {th }}$ centuries}

In this section I will outline the crucial societal conditions that shaped the respective fertility transition pathways in the $19^{\text {th }}$ and $20^{\text {th }}$ centuries. 


\subsection{Western populations}

Economic, social, cultural, political and policy, as well as many other effects ${ }^{7}$ (Notestein 1945, 1953; Coale 1973; Lesthaeghe/van de Kaa 1986; Lesthaeghe 2010) were instrumental in shaping the most important fertility fluctuations in Western populations (Fig. 2 and Fig. 6, panel A).

\section{The Great Depression: The principal cause of low completed cohort fertility} of women born in the 1900s

In at least ten of the 16 populations for which data are available, CTFRs bottomed out among women born in the 1900s with values of 1.8-2.2 births per woman, i.e. considerably below the replacement level given the mortality conditions of the time (Fig. 2, panels A-D, and Fig. 6, panel A). ${ }^{8}$ In Europe as well as in the United States, the Great Depression of the late 1920s and the 1930s was identified as the principal cause of this fertility nadir.

In his recently published book, Labor's Love lost: The Rise and Fall of the Working-Class Family in America, Cherlin (2014) describes in great detail changes in American family life over the past two centuries. He characterizes "the Great Depression [as] a cataclysmic event in the United States in its depth and duration" (Cherlin 2014: 60). Based on contemporary sociological research of Komarovsky (1940), Cherlin discusses the effect of the Depression on reproductive behavior.

Their sex lives often deteriorated: in twenty-two out of thirty-eight families for which adequate information was collected, the frequency of sexual relations declined - including four families in which sex stopped altogether. In some cases, however, couples reduced sexual activity not because of emotional strain but in order to lower the chance that the wife would become pregnant. Without modern means of birth control such as the pill or the IUD, financially struggling couples did what they could to avoid having another mouth to feed. One parent said, "It is a crime for children to be born when the parents haven't got enough money to have them properly." (Cherlin 2014:79).

Hobcraft and Kiernan (1995: 53-54) observed that

the key element in understanding the low rates of entry into parenthood in several European countries during the 1930s is that times were hard. The prolonged economic depression, with insecurity of employment and often difficulties in obtaining adequate housing, was a critical factor. The insecurities involved in becoming a parent during the 1930 s were of course much greater than today, owing to the poor development of the welfare state as a means of ameliorating and smoothing the

7 Notestein (1953: 142) also reminded us that "it is impossible to be precise about the various causal factors".

8 The ten populations with CTFRs between 1.8 and 2.2 are: Denmark, Norway, Sweden, Belgium France, England and Wales, Austria, Switzerland, West Germany, and the Czech Republic; data are not available for Finland, Australia, and New Zealand. 
costs and chance variations in the prolonged process of childrearing. [...] The low levels of entry into childhood through successful postponement [of conception] of the 1930s are all the more remarkable in the context of the relatively ineffective methods of fertility control available at that time. There must have been many more couples than those who succeeded in avoiding entry into parenthood who experienced accidental pregnancies through inability to control fertility.

\section{Mid-20th century prosperity: The principal cause of high completed cohort fertility of women born in the 1930s}

Relatively high childbearing is understandable in light of Cherlin's (2014: 115) characterization of the living conditions of American families in the post-World War II years.

Why did young couples have so many children? One reason lay in the unique life histories of the generation who were in their twenties and thirties. They experienced the Great Depression as children or adolescents and then a world war erupted as they reached adulthood. After enduring these two cataclysmic events, the "great generation," as they are sometimes called, was pleased in peacetime to turn inward toward home and family. [...] Family life was the domain in which they found [...] security. Raising children provided a sense of purpose to adults who had seen how fragile the social world could be. [...] Moreover, conditions were favorable for family formation and fertility: unemployment rates were low, wages were rising, and the government had enacted the GI Bill, which offered low-interest home mortgage loans to veterans so that they could buy single-family homes. [...] Employers in the rapidly expanding American economy were forced to offer higher wages in order to attract new workers because they were in short supply.

Hobcraft and Kiernan (1995: 55-56) portrayed the favorable conditions for family formation and childbearing created by healthy economies and by family policies in the middle of the $20^{\text {th }}$ century in Europe as follows.

The modern welfare state was established predominantly in the period following the 1939-45 War. This clearly changed the costs of childbearing in substantial ways. The costs of education, health, and welfare of children were increasingly covered by the state rather than directly by the parents themselves. The provision of a security blanket also considerably reduced the uncertainties surrounding the future ability to provide for children. The 1950s and 1960s were also a period of unprecedented economic growth and real wages increased substantially. The advent of Keynesian macroeconomic policies appeared to have created an era of sustained permanent employment, thereby adding to the anticipated security for parenthood. Moreover, the massive construction of housing following the War ultimately improved quality and access. In the realm of ideas, we would see the widespread continuation of compulsory conscription for males as breaking the nexus of home attachment to their families of origin. This almost certainly played a part in accelerating the establishment of independent living, which usually involved marriage. In turn, this contributed to earlier entry into parenthood. 
As demonstrated in section 3, even though there were striking similarities in the fertility trends among countries of the Western fertility transition pathway there was also a significant amount of diversity and variation (Cf. Fig. 3 and 7). An analysis by Van Bavel and Reher (2013) of the diversity in the timing, length, magnitude and volume of the baby boom led them to conclude that the conventional explanations appear to be only a limited part of the story. They argue that other demographic and policy factors than the enhanced wellbeing and enlightened policies outlined above might have been instrumental in generating the baby boom, such as a rise in nuptiality, the role played by cultural factors like political and family attitudes and religion, and the possible influence of pronatalist policies.

\section{The complexities surrounding childbearing and family life: The milieu determining low fertility of the 1950s-1970s birth cohorts}

In most of the Western countries the CTFRs for women born during the 1950s and 1960 s were very close to two births per woman. In the historical context of the second half of the $20^{\text {th }}$ century this was a low level for these countries. Nonetheless, this was close to the replacement level. And it was higher than in any of the other regions, i.e. the South European, Central and East European, and the East and South-East Asian populations.

There is an extraordinary wealth of literature dealing with the economic, social, political, policy, cultural, gender relations, normative, attitudinal and other conditions influencing recent and contemporary childbearing and family life (inter alia, Bianchi et al. 2006; Frejka et al. 2008; Goldscheider et al. 2015; Kreyenfeld/Konietzka 2017; Lesthaeghe 2010; McDonald 2002, 2006; McDonald/Moyle 2010; Myrskylä et al. 2013; Neyer 2003; Rindfuss/Choe 2015, 2016; Sobotka 2004; Sobotka/Beaujouan 2014; Stock et al. 2013; Thévenon 2011). This literature discusses the various circumstances that shaped Western childbearing trends. A prominent recent development has been that increasing numbers of women have been entering the public sphere. Goldscheider et al. (2015) labeled this as the first half of the gender revolution. Not only were women working, they were also the principal managers of the household, and they were taking care of most of the childrearing (in addition to childbearing). Even though the second part of the gender revolution (men increasingly getting involved with household and childrearing responsibilities) was progressing, the pressures women were subjected to were apparently having a dampening effect on childbearing.

Although many other circumstances, such as employment insecurity, working conditions, and the need for education and training, were affecting fertility, it is the gender revolution that has recently attracted special attention. Three prominent papers (Esping-Andersen/Billari 2015; Goldscheider et al. 2015; Anderson/Kohler 2015) have dealt with this topic, and the authors have concluded that the gender revolution may or will generate a reversal of fertility trends.

Esping-Andersen and Billari "posit a return to 'more family' as gender egalitarianism gains increasingly dominant normative status" (2015: 3). Underlying "more family," inter alia, is a reversal of fertility trends and a "stabilization of the quan- 
tum of childbearing" (2015: 2). Goldscheider et al. are very careful in their formulations regarding the relationship between the ongoing gender revolution and fertility. Specifically, "there is growing evidence that men's increasing involvement in homemaking and childcare may potentially increase fertility" (2015: 222). And "this approach, which assumes that committed partner and parental relationships are indeed important to most people further implies that men's increased involvement in the home, the second half of the gender revolution, has the promise of increasing [...] fertility [...]" (2015: 229). A number of references listed by Goldscheider et al. indicate an implicit conclusion that a fertility reversal and turnaround [meaning increase] is under way in countries where the gender revolution is advanced. However, skepticism regarding such conclusions is justified because the analysis in the above sections as well as data from additional research (Frejka et al. 2016a/b) document that thus far there is no evidence of a fertility reversal in developed countries.

A central conclusion of the Anderson and Kohler (2015) paper is a new portrayal of the "stylized demographic transition extended to show [a] gender equity catchup" illustrated by a turnaround in the birth rate, shown in their Figure 4 on page 394. Ultimately the death rate and the birth rate equal each other, resulting in an equilibrium. This depiction appears to be misleading on several counts.

In the first place, the Anderson/Kohler Figure 4 implies that there is only a single pathway for the fertility transition, whereas the present paper demonstrates that to date there have been four such pathways and that there might be more in the future. The dip in the early $20^{\text {th }}$ century cohort TFRs occurred only in the Western fertility transition pattern, but Anderson and Kohler consider it a universal component of the fertility transition in all countries. Secondly, the fertility nadir and subsequent recovery experienced by women born early in the $20^{\text {th }}$ century in Northern and Western Europe, and in the overseas countries with populations mostly of European origin, was mainly caused by the dire economic and social conditions during the Great Depression of the 1930s followed by the favorable conditions of the 1950s and 1960s. Thus to label the fertility dip and subsequent increase of the early $20^{\text {th }}$ century birth cohorts as a "gender equity catch-up" is questionable since it was caused by other factors. Thirdly, the Anderson/Kohler Figure 4 implies that toward the end of the demographic transition (end of their phase 5 and in phase 6) mortality and fertility stabilize in a balanced equilibrium in which these rates equal each other. As noted above, life expectancy has been increasing throughout the $20^{\text {th }}$ century and there is a consensus that mortality will continue to decline for several decades to come. And the future of fertility trends is unclear with a declining tendency up to the present time. In sum, a low mortality and low fertility equilibrium has not yet materialized.

\subsection{South European populations}

The fundamental determinants shaping fertility trends in Southern Europe are analogous to those in the Western populations. There are however circumstances powerfully depressing childbearing in recent decades and reinforcing the burdens and pressures women are subjected to in Southern Europe (Delgado et al. 2008; De Rose et al. 2008; Rindfuss/Choe 2016). Prominent among them were the following. 
To begin with, these societies have been intensely patriarchal. Even though gender inequalities have been weakening during the recent past, they continue to operate, especially in the family. According to De Rose et al. (2008: 687-688):

\begin{abstract}
In Italy during the last 40 years, the public gender system changed in an even sense: Women now have access to any profession, they achieve a higher educational level than men, and, when employed, they work almost as hard as men, especially before entering motherhood. At the same time, however, the couple's sharing of housework is heavily unbalanced - not only when the woman is a housewife (in the traditional logic of 'job sharing'), but even when she works full-time. Women need to and want to work in order to avoid an income reduction as well as a loss of role and identity. At the same time, spending long hours on household chores, without any significant help from the husband, contributes to making low fertility more than a choice.
\end{abstract}

Furthermore, many facets of the labor market tend to have a depressing impact on childbearing. In general, unemployment is high, particularly young adult unemployment; work hours tend to be long; those who are employed are significantly protected making it difficult for them to be fired and, at the same time, there is scant room for hiring new, young employees; many employees have inferior working conditions with few protections and benefits; there are few possibilities for part-time work. High housing costs are also making it difficult for young people to buy a flat or a house. Finally, the persistence of strong ties between parents and children, although apparently counterintuitive, helps to maintain the gap between desired and actual fertility (De Rose et al. 2008: 690):

Parents invest a lot in their (only) child and a very high cost-value is attributed to these children, which in Italy is shouldered entirely by the family. Not having a second or third child seems to be resulting from the fear of lowering the child's quality of life, who is highly protected by its parents. Moreover, as the children's prospects of social mobility have been low or nonexistent for a long time, Italian families show little enthusiasm to push their children 'out of the family nest'.

\title{
4.3 Central and East European populations
}

During the $19^{\text {th }}$ and early $20^{\text {th }}$ centuries, the cluster of the "usual suspects" of social, economic, political, and cultural conditions shaped fertility trends in Central and East European populations. The few populations - Czech, Slovak, Russian and Estonian - for which trend curves are available attest to that. The Czech example is particularly interesting; the dip in the cohort total fertility rate trend below two births per woman from the 1895 to the 1909 birth cohorts is a clear case of the impact of the Great Depression on childbearing behavior (Fig. 4 and Fig. 6, panel C).

After the Second World War political and policy circumstances overwhelmingly affected other societal conditions and engendered the relatively stable fertility trends with CTFRs around two births per woman in the Central and East European populations (Fig. 4 and 6, panel C). In the words of Frejka and Gietel-Basten (2016: 9): 
Three mutually reinforcing factors - the technologically lagging and labor intensive inefficient socialist economies which generated a continuous demand for labor; a pro-natalist ideology and policies; and the authoritarian political system restricting personal freedom - created conditions which were generally conducive for early and universal childbearing. These conditions included job security, low-cost housing, free education, free health care, various entitlements associated with child birth and childrearing, as well as limited career opportunities and leisure activities. The citizenry of the state socialist countries had grown accustomed to a relatively stable and predictable existence, although standard living conditions were worse than in Western countries, and there were numerous disturbing concomitants to this lifestyle, such as curtailed civil liberties and shortages of everyday and long-lasting consumer goods (Frejka 2008; Sobotka 2004, 2011).

Frejka and Gietel-Basten (2016: 10) summarized the rather unique conditions following the collapse of state socialism around 1990 as follows:

Mutually reinforcing features of the transition to contemporary capitalism - the quest for maximizing profits and productivity, the employment of advanced increasingly complex technologies, competitive labor markets, a propensity for a low priority for social obligations towards workers and society, as well as the spread of modern contraceptives - created considerably more restraining conditions for childbearing. These included job and income insecurity, an increasing pressure to acquire more education, expensive housing, lesser and declining birth and childrearing entitlements, increased uncertainty of spousal relationships as well as expanded personal freedom, the availability of a variety of career opportunities, consumption attractions and leisure activities. All of a sudden, people were exposed to societal conditions which made it more difficult to earn a living, more demanding to reconcile the familywork conflict, and under which various costs previously borne by the paternalistic state became the responsibility of individuals and families (Frejka 2008; Sobotka 2011). All told, the balance shifted from circumstances generally encouraging early marriage and childbearing with a distinct propensity for a two-child family, to circumstances postponing union formation and childbearing as well as inhibiting family size. The propensity for two-child families started to weaken, shares of one-child families increased everywhere and even became the most prevalent in the Russian Federation and Ukraine.

\subsection{East and South-East Asian populations}

The outstanding characteristic of the conditions influencing fertility in East and South-East Asia is the fact that modern economic and social development started as late as in the middle of the $20^{\text {th }}$ century. Once it did get under way it progressed at an unusually fast pace. Economies grew at rates in excess of seven per cent per year between the early 1960s and the 1990s. Four of these countries - Hong Kong, Singapore, South Korea, and Taiwan - deservedly earned the epithet The Four Asian Tigers. Japan's economic development got under way much earlier, in the 1860s, and further expanded during the 1920s. Moreover, thanks to its post-World War Two economic miracle Japan became the world's second largest economy. These 
economic advances were accompanied by other societal developments, including significant declines in mortality and fertility (Fig. 5 and 6, panel D).

Social and economic factors depressing fertility in East and South-East Asia might have been more forceful than elsewhere, explaining the rapid fertility decline of the past half century resulting in the very low cohort fertility rates of the generations born in the 1960s and early 1970s (Frejka et al. 2010; Jones et al. 2009; Rindfuss/Choe 2015, 2016).

The economies generated a robust demand for labor and single as well as married young women were eager to satisfy this demand. Large proportions of women acquired an advanced education and joined the labor force. At the same time, patriarchal gender relationships which dominated family life for centuries hardly changed at all. As a rule, men do not participate in housekeeping activities and leave most of the raising of children to their wives. Women are expected not only to run the household, and bear and raise children, but frequently are also expected to care for the elderly. Employers are focused on production and profits. Providing family-friendly work conditions for women is beyond their horizon. Consequently, many women are delaying marriage and childbearing. Social conditions have not kept pace with changing economic realities (Frejka et al. 2010: 602).

\section{$5 \quad$ Summary and conclusions}

Available cohort fertility data for the $19^{\text {th }}$ and $20^{\text {th }}$ centuries of 36 populations in Europe, in the overseas populations of European origin, and in East and South-East Asia have been assembled for this study. The analysis of these data has yielded the following principal findings.

The analysis of cohort total fertility rates to date specifies four fertility transition pathways during the late $19^{\text {th }}$ and the $20^{\text {th }}$ centuries. When sufficient data become available for other populations, other types of fertility transition pathways might appear. The four pathways are:

- The Western fertility transition pathway is characterized by major fluctuations in fertility. The birth cohorts of the mid-19 ${ }^{\text {th }}$ century experienced CTFRs around 4-5 births per woman, which declined to a nadir of \pm 2 births per woman among the early $20^{\text {th }}$ century cohorts. The 1920 s and early 1930s CTFRs then increased to a broad range of 2.1-3.6 births per woman, followed by another decline to 1.8-2.2 births per woman in the 1950s and 1960 s cohorts, which remained fairly stable albeit with a moderate trend of further decline.

- The South European fertility transition pathway is characterized by a relatively stable CTFR decline from 5 births per woman, interrupted by a plateau among the 1920s-1930s cohorts, all the way down to CTFRs of 1.4-1.7 births per woman in the late 1960s and early 1970s cohorts.

- The Central and East European fertility transition pathway is characterized by a CTFR decline among late $19^{\text {th }}$ century cohorts to a stable band of about 1.8-2.1 births per woman in the 1920s-1950s birth cohorts, followed by a CTFR decline to $1.6-1.8$ in the 1960 s and early 1970 s cohorts. 
- The East and South-East Asia fertility transition pathway is characterized by a rapid decline of CTFRs starting as late as the middle of the $20^{\text {th }}$ century from about 5 births per woman in the 1920s birth cohorts to CTFRs equal to 1.2-1.6 births per woman in the late 1960s and early 1970s cohorts.

In all four fertility transition pathways a majority of the cohort total fertility rates were below replacement level in the 1960s and early 1970s birth cohorts, and did not indicate a propensity to increase. There were some exceptions, namely Norway, New Zealand, and the United States with above replacement fertility.

The exploration of societal conditions shaping mortality and fertility trends in the $19^{\text {th }}$ and $20^{\text {th }}$ centuries confirm Notestein's conclusions that it is a complex combination of "technological, social, economic, and political developments" as well as cultural and ideational effects that shape those trends and that it is "impossible to be precise about the various causal factors" (1953: 142) At times the primary factors were economic, as in the Great Depression of the 1930s or the post-war prosperity of the 1960s in Western countries, however these economic factors had numerous political, cultural, policy and other facets that were also important in shaping the fertility trends. In other settings, the primary factors were the political system and social policies, namely in the era of state socialism in Central and Eastern Europe. In other settings, the patriarchal nature of the society was the prime factor, as in Southern Europe and in East and South-East Asia. However, many other factors were in play in these contexts as well.

Extensive research of other scholars has revealed that since the last third of the $19^{\text {th }}$ century mortality has declined continuously, and life expectancy has globally increased by the end of the $20^{\text {th }}$ century. Furthermore, mortality is reliably projected to decline further, and life expectancy to increase till the mid-21 ${ }^{\text {st }}$ century (Oeppen/ Vaupel 2002; Shkolnikov et al. 2011). This implies that thus far the demographic transition has not led to an equilibrium of relatively stable low mortality and stable low fertility. Mortality continues to decline steadily while fertility trends are in flux with unclear prospects. If this persists, a consensus might finally emerge that this state be regarded as a new type of "equilibrium" - a post-transition regime of low mortality and low fertility variability.

The principal finding from the cohort fertility data analysis in this study is that to date there have been four distinct pathways of fertility decline. These pathways were apparently generated by fundamental differences in the social, economic, political, cultural and ideational developments in societies that have moved to relatively low mortality and low fertility. Considerable work lies ahead: to generate long-term cohort fertility data for additional populations, to discern whether other fertility transition pathways are occurring, to reveal the determinants of these pathways, and what the outcomes of mortality and fertility trends might be.

This study can be considered complementary to the findings based primarily on period fertility data of Basten et al. (2014: 39-146) in the volume by Lutz et al. (2014) on World Population and Human Capital in the Twenty-First Century, which demonstrated the importance of many different factors shaping fertility. Furthermore, it concluded that "...the locus of low fertility is increasingly moving away from 'Old 
Europe' and towards the rapidly developing economies of East Asia, Latin America, and the Middle East" and that "... a global convergence of fertility around replacement level appears unlikely".

\section{Acknowledgements}

Thoughtful comments on earlier drafts from Andrew Cherlin, Michaela Kreyenfeld, Zdeněk Pavlík, John Ross, Tomáš Sobotka, Vladimir Shkolnikov, Claudio Stern, Charles Westoff, and two anonymous reviewers are gratefully acknowledged.

The original version of this paper was presented at The MPIDR 2nd Human Fertility Database Symposium, Berlin, June 2016 and was published as an MPIDR Working Paper WP 2016-012, November 2016.

\section{References}

Anderson, Thomas; Kohler, Hans-Peter 2015: Low Fertility, Socioeconomic Development, and Gender Equity. In: Population and Development Review 41,3: 381-407 [doi: 10.1111/j.1728-4457.2015.00065.x].

Basten, Stuart; Sobotka, Tomáš; Zeman, Kryštof 2014: Future Fertility in Low Fertility Countries. In: Lutz et al. (Eds.): World Population and Human Capital in the TwentyFirst Century. Oxford University Press.

Bianchi, Suzanne; Robinson, John; Milkie, Melissa 2006: Changing Rhythms of American Family Life. New York: Russell Sage Foundation.

Bongaarts, John; Feeney, Griffith 1998: On the quantum and tempo of fertility. In: Population and Development Review 24,2: 271-291 [doi: 10.2307/2807974].

Carr-Saunders, Alexander M. 1936: World Population: Past Growth and Present Trends. Oxford: Clarendon Press.

Cherlin, Andrew J. 2014: Labor's Love lost: The Rise and Fall of the Working-Class Family in America. The Russell Sage Foundation.

Coale, Ansley J. 1973: The Demographic Transition. In: IUSSP International Population Conference. Liége. Volume I. 53-72.

Delgado, Margarita; Meil, Gerardo; Zamora López, Francisco 2008: Spain: Short on children and short on family policies. In: Demographic Research 19,27: 1059-1104 [doi: 10.4054/DemRes.2008.19.27].

De Rose, Alessandra; Racioppi, Filomena; Zanatta, Anna Laura 2008: Italy: Delayed adaptation of social institutions to changes in family behaviour. In: Demographic Research 19,19: 665-703 [doi: 10.4054/DemRes.2008.19.19].

Esping-Andersen, Gøsta; Billari, Francesco C. 2015: Re-theorizing Family Demographics. In: Population and Development Review 41,1: 1-31 [doi: 10.1111/j.17284457.2015.00024.x].

Festy, Patrick 1979: La Fécondité des Pays Occidentaux de 1870 a 1970. In: Travaux et Documents Cahier no. 85. Presses Universitaires de France.

Frejka, Tomas 2008: Determinants of family formation and childbearing during the societal transition in Central and Eastern Europe. In: Demographic Research 19,7: 139-170 [doi: 10.4054/DemRes.2008.19.7]. 
Frejka, Tomas 2011: The Role of Contemporary Childbearing Postponement and Recuperation in Shaping Period Fertility Trends. In: Comparative Population Studies Zeitschrift für Bevölkerungswissenschaft 36,4: 927-958 [doi: 10.4232/10.CPoS-201120en].

Frejka, Tomas; Gietel-Basten, Stuart 2016: Fertility and Family Policies in Central and Eastern Europe after 1990. In: Comparative Population Studies 41,1: 3-56. [doi: 10.12765/CPoS-2016-03en].

Frejka, Tomas; Goldscheider, Fran; Lappegård, Trude 2016a: The Second Half of the Gender Revolution and Fertility. In: Proceedings of 2016 Annual Meeting of Population Association of America, session 214. Washington D.C.

Frejka, Tomas; Goldscheider, Fran; Lappegård, Trude 2016b: The Gender Revolution and Fertility. In: Proceedings of 2016 European Population Conference. Session 43. Mainz, Germany.

Frejka, Tomas; Jones, Gavin W.; Sardon, Jean-Paul 2010: East Asian Childbearing Patterns and Policy Developments. In: Population and Development Review 36,3: 579 606 [doi: 10.1111/j.1728-4457.2010.00347.x].

Frejka, Tomas et al. 2008: Childbearing Trends and Policies in Europe. In: Demographic Research, Special collection 7, 19,2: 5-14.

Goldscheider, Frances; Bernhardt, Eva; Lappegård, Trude 2015: The Gender Revolution: A Framework for Understanding Changing Family and Demographic Behavior. In: Population and Development Review 41,2: 207-239 [doi: 10.1111/j.1728-4457.2015.00045.x].

Hajnal, John 1965: European Marriage Patterns in Perspective. In: Glass, David Victor; Eversley, David E.C. (Eds.): Population and History: Essays in Historical Demography. London: 101-145.

Hamilton, Brady E.; Cosgrove, Candace M. 2010: Central birth rates, by live-birth order, current age, and race of women in each cohort from 1911 through 1991: United States, 1960-2005. Hyattsville, MD: National Center for Health Statistics. 2012 addition with 2006-2009 data [http://www.cdc.gov/nchs/nvss/cohort_fertility_tables.htm, 31.07.2017].

Heuser, Robert L. 1976: Fertility tables for birth cohorts by color: United States, 1917-73. Rockville, MD: U.S. Department of Health, Education, and Welfare, National Center for Health Statistics [http://www.cdc.gov/nchs/data/misc/fertiltbacc.pdf, 27.06.2017]

Hobcraft, John; Kiernan, Kathleen 1995: Becoming a parent in Europe. In: European Population Conference 1995. Evolution or Revolution in European Population. Vol. 1. Plenary Sessions. Milano. 27-65.

Human Fertility Database 2016: Max Planck Institute for Demographic Research, Germany, Vienna Institute of Demography, Austria [www.humanfertility.org, 27.06.2017].

Jones, Gavin W.; Tay Straughan, Paulin; Chan, Angelique (Eds.) 2009: Ultra-low Fertility in Pacific Asia: Trends, Causes and Policy Issues. London: Routledge.

Kirk, Dudley 1946: Europe's Population in the Interwar Years. Princeton: Princeton University Press.

Kirk, Dudley 1996: Demographic Transition Theory. In: Population Studies 50,3: 361-387 [doi: 10.1080/0032472031000149536].

Komarovsky, Mirra 1940: The Unemployed Man and His Family. New York: Octagon Books.

Kreyenfeld, Michaela; Konietzka, Dirk (Eds.) 2017: Childlessness in Europe: Contexts, Causes, and Consequences. Springer Publishing Co [doi: 10.1007/978-3-319-44667-7]. 
Landry, Adolphe 1909: Les trois theories de la population. In: Revue Scientia.

Landry, Adolphe 1934: La revolution démographique. Paris: Sirey.

Lesthaeghe, Ron 2010: The unfolding story of the Second Demographic Transition. In: Population and Development Review 36,2: 211-251 [doi: 10.1111/j.17284457.2010.00328.x].

Lesthaeghe, Ron; van de Kaa, Dirk 1986: Twee Demografische Transities? In: Lesthaeghe, Ron; van de Kaa, Dirk (Eds.): Bevolking: Groei en krimp.Mens en Maatschappij, book supplement. Deventer: Van Loghum-Slaterus: 9-24.

Lorimer, Frank 1946: The Population of the Soviet Union: History and Prospects. Princeton: Princeton University Press.

Lutz, Wolfgang; Butz, William P.; KC, Samir (Eds.) 2014: World Population and Human Capital in the Twenty-First Century. Oxford University Press.

McDonald, Peter 2002: Sustaining fertility through public policy: The Range of Options. In: Population (English edition) 57,3: 417-446 [doi: 10.2307/3246634].

McDonald, Peter 2006: An Assessment of Policies that Support Having Children from the Perspectives of Equity, Efficiency and Efficacy. In: Vienna Yearbook of Population Research 4: 213-234.

McDonald, Peter; Moyle, Helen 2010: Why do English-speaking countries have relatively high fertility? In: Journal of Population Research 27,4: 247-273 [doi: 10.1007/ s12546-010-9043-0].

Moore, Wilbert E. 1945: The Economic Demography of Eastern and Southern Europe. Princeton: Princeton University Press.

Myrskylä, Mikko; Goldstein, Joshua R.; Chen, Yen-hsin Alice 2013: New cohort fertility forecasts for the developed world: Rises, Falls, and Reversals. In: Population and Development Review 39,1: 31-56 [doi: 10.1111/j.1728-4457.2013.00572.x].

Neyer, Gerda 2003: Family Policies and Low Fertility in Western Europe. MPIDR Working Paper. WP 2003-021 [http://www.demogr.mpg.de/papers/working/wp-2003-021. pdf, 27.06.2017].

Notestein, Frank W. 1945: Population-The Long View. In: Schultz, Theodore W. (Ed.): Food for the World. Chicago: University of Chicago Press: 36-57.

Notestein, Frank W. 1953: Economic Problems of Population Change. In: Proceedings of the Eighth International Conference of Agricultural Economists. New York: 13-31.

Notestein, Frank W. et al. 1944: The Future Population of Europe and the Soviet Union: Population Projections, 1940-1970. Geneva: League of Nations.

Observatoire Démographique Européen (ODE) 2012: No longer in existence. Selected country tables

Oeppen, James E.; Vaupel, James W. 2002: Broken limits of life expectancy, In: Science 296: 1029-1031.

Pavlík, Zdeněk 1964: Nástin Populačního Vývoje Světa (The Evolution of World Population Growth). Prague: Nakladatelství Československé Akademie Věd.

Puur, Allan 2016: Personal communication. 13 May.

Rindfuss, Ronald R.; Choe, Minja Kim (Eds.) 2015: Low and Lower Fertility. Springer Publishing Co [doi: 10.1007/978-3-319-21482-5].

Rindfuss, Ronald R.; Choe, Minja Kim (Eds.) 2016: Low Fertility, Institutions, and their Policies. Springer Publishing Co [doi: 10.1007/978-3-319-32997-0]. 
Ryder, Norman B. 1951: The cohort approach: Essays in the measurement of temporal variations in demographic behavior. PhD dissertation, Princeton University.

Ryder, Norman B. 1964: The process of demographic translation. In: Demography 1,1: 57-82.

Sardon, Jean-Paul 1991: Generation replacement in Europe since 1900. In: PopulationE 3: 15-32, Table 5: 28-29.

Shkolnikov, Vladimir M. et al. 2011: Steep Increase in Best-Practice Cohort Life Expectancy. In: Population and Development Review 37,3: 419-434 [doi: 10.1111/j.17284457.2011.00428.x].

Sobotka, Tomáš 2004: Postponement of childbearing and low fertility in Europe. PhD Thesis, University of Groningen. Amsterdam: Dutch University Press.

Sobotka, Tomáš 2011: Fertility in Central and Eastern Europe after 1989. Collapse and gradual recovery. In: Historical Social Research (Special issue: Fertility in the $20^{\text {th }}$ Century: trends, policies, theories, discourses) 36,2: 246-296.

Sobotka, Tomáš 2016: The European Middle Way? Low Fertility, Family Change, and Gradual Policy Adjustments in Austria and the Czech Republic. In: Rindfuss, Ron; Choe, Minja Kim (Eds.): Low Fertility, Institutions, and their Policies. Springer Publishing Co.: 131-163.

Sobotka, Tomáš; Beaujouan, Éva 2014: Two Is Best? The Persistence of a Two-Child Family Ideal in Europe. In: Population and Development Review 40,3: 391-419 [doi: 10.1111/j.1728-4457.2014.00691.x].

Spéder, Zsolt 2016: Fertility Decline and the Persistence of Low Fertility in a Changing Policy Environment: A Hungarian Case Study. In: Rindfuss, Ron; Choe, Minja Kim (Eds.): Low Fertility, Institutions, and their Policies. Springer Publishing Co.: 165-194.

Stankuniene, Vlada 2016: Personal communication. 9 May.

Stock, Günter et al. (Eds.) 2013: Zukunft mit Kindern - Fertilität und gesellschaftliche Entwicklung in Deutschland, Österreich und der Schweiz (A Future with Children: Fertility and Development of Society in Germany, Austria, and Switzerland). Frankfurt/ New York: Campus Verlag.

Thévenon, Olivier 2011: Family Policies in OECD Countries: A Comparative Analysis. In: Population and Development Review 37,1: 57-87 [doi: 10.1111/j.17284457.2011.00390.x].

Thompson, Warren S. 1929: Population. In: American Journal of Sociology 34,6: 959 975.

Tymicki, Krzysztof 2016: Personal communication. 26 May.

Van Bavel, Jan; Reher, David S. 2013: The Baby Boom and Its Causes: What We Know and What We Need to Know. In: Population and Development Review 39,2: 257-288.

Zakharov, Sergei 2008: Russian Federation: From the first to second demographic transition. In: Demographic Research 19,24: 907-972 [doi: 10.4054/DemRes.2008.19.24].

Zakharov, Sergei 2016: Personal communication. 4 May.

Zeman, Kryštof 2016: Personal communication 2 May. 


\section{Comparative Population Studies}

wWW.comparativepopulationstudies.de

ISSN: 1869-8980 (Print) - 1869-8999 (Internet)

\section{Published by}

Prof. Dr. Norbert F. Schneider

Federal Institute for Population Research D-65180 Wiesbaden / Germany

\section{(cc) BY-SA}

2017

\section{Managing Editor}

Frank Swiaczny

\section{Assistant Managing Editor}

Katrin Schiefer

\section{Copy Editor}

(Selected Articles in German)

Dr. Evelyn Grünheid

\section{Layout}

Beatriz Feiler-Fuchs

E-mail: cpos@bib.bund.de

\section{Scientific Advisory Board}

Paul Gans (Mannheim)

Karsten Hank (Cologne)

Johannes Huinink (Bremen)

Michaela Kreyenfeld (Rostock)

Marc Luy (Vienna)

Notburga Ott (Bochum)

Peter Preisendörfer (Mainz)

Nikola Sander (Groningen)

Zsolt Spéder (Budapest)

\section{Board of Reviewers}

Martin Abraham (Erlangen)

Laura Bernardi (Lausanne)

Hansjörg Bucher (Bonn)

Claudia Diehl (Konstanz)

Andreas Diekmann (Zurich)

Gabriele Doblhammer-Reiter (Rostock)

Jürgen Dorbritz (Wiesbaden)

Anette Eva Fasang (Berlin)

E.-Jürgen Flöthmann (Bielefeld)

Alexia Fürnkranz-Prskawetz (Vienna)

Beat Fux (Salzburg)

Joshua Goldstein (Berkeley)

Sonja Haug (Regensburg)

Hill Kulu (Liverpool)

Aart C. Liefbroer (The Hague)

Kurt Lüscher (Konstanz)

Emma Lundholm (Umeå)

Nadja Milewski (Rostock)

Dimiter Philipov (Vienna)

Roland Rau (Rostock)

Tomáš Sobotka (Vienna)

Jeroen Spijker (Barcelona)

Olivier Thévenon (Paris)

Helga de Valk (Brussels)

Heike Trappe (Rostock)

Michael Wagner (Cologne) 